\title{
God and Universities
}

\author{
John B. Cobb, Jr.
}

\begin{abstract}
In this article, 'God and Universities', I argue that the exclusion of God from contemporary academia did not come about because of evidence or argument. Rather, it is due to the fact that the scientific adherence to the treatment of the objective world as self-contained, was increasingly applied to everything. Also the limiting of acceptable thinking to topics falling within one academic discipline or another had no place for continuing a discussion of the topic. The self-assurance of academia is beginning to weaken. The exclusion of God as a causal factor, is part of the exclusion of purpose including human purpose. This leads to implausible explanations that are assumed to be needed but rarely explicitly defended. If the evidence for the importance of subjective experience is allowed, the door will be opened to changes that eventually could reinstate God.
\end{abstract}

Keywords: God, university, objective world, purpose, subjective experience

\section{I}

My interest in this article, is to address the social occurrence of belief in God in relation to real reasons to believe or disbelieve. But, global culture consists of so many subcultures, and there are so many parts of the world where the situation is different, that I am limiting my generalizations to the university. Although the cultures of universities also vary, there is also some commonality around the world. Generalizing about this can be meaningful even if there are many exceptions.

The university culture of which I speak is not limited to university campuses. A high percentage of people in government, in professions, and in industry have been trained and socialized in universities. They also partake in 
that culture, although in some cases it is more mixed with other influences than what one encounters among the permanent denizens of universities.

My first generalization is that God is excluded from the culture of universities. There are very few places where one would find support for a claim that the adequate explanation of some event or phenomenon required the inclusion of God among the causes. At the heart of the scientific method developed during the Enlightenment is the view that the natural world is selfcontained. The formulation of this idea very intentionally excluded any role for God in what happens in the natural world.

By the twentieth century the exclusion of God became equally systematic and exhaustive when the topic is human history or the explanation of human experience. One might think that the increased acceptance of religious studies in the academy over the last two or more decades, was an opening for God (cf. Prozesky 1992). But the study or religious experience has gained a larger place in universities at the price of accepting university norms. The university study of religious experience must be value-free, and that is a code for being free of any belief that God might play a role.

In some philosophy departments there are still courses in which arguments for the existence of God are considered. And, there are still some professors who support God's existence. But I think it safe to say that the culture of the university cuts against this position and that it is disappearing. The arguments are now generally only of historical interest, not ways of responding to urgent questions.

But, are not schools of theology also part of the university? In some instances, yes. Is not God affirmed in these schools? In some instances, yes. This is the last significant exception to my generalization. But it is not as significant as those outside the schools of theology might suppose.

Most of the professors of most of these schools fully accept the university norms. Although various beliefs about God are discussed in courses in Bible, church history, and history of religions, university norms are rigorously followed. In these courses, God plays no role in explaining historical events. The one place where there is likely to be discussion of God and what God does is in systematic theology or church doctrine. Even here, many professors prefer to avoid direct statements about God, or what God does. In many cases, the talk is more of the impossibility of really knowing anything about God than of God. What until recently was understood to be 'theology' cannot be understood as an academic 'discipline'. Its confessional 
character is not acceptable. Accordingly, 'theology' tends to be reshaped into conformity to the norms of an academic discipline or else dropped from the curriculum.

I have been speaking of schools of theology that are part of modern research universities. The pressure there is to conform to university norms. There are also schools of theology in church schools that do not aspire to recognition in university circles or are entirely free standing. Some of these are more closely tied to conservative Christian communities than to university culture. My generalizations about universities do not apply to them.

\section{II}

For many centuries higher education in the West was understood to be in the service of God and God's church. So the current situation reflects a change that is quite drastic. Even a hundred years ago it took some courage in many universities explicitly to announce that one was an atheist. Today, it takes the same kind of courage to announce that one is a theist. If one went on to say that one believed that the activity of God should be included as an explanatory factor in one or another academic discipline, one's job would be in jeopardy. Atheists are no more tolerant of serious theists than theists, when they were dominant, were tolerant of atheists.

Some people suppose that the university culture is shaped by research into the evidence. There is some connection, but remarkably little. I see no reason to think that the evidence of physics or psychology or history is less favourable to belief in God now than then. What has brought about the change?

My judgment is that the deepest change has been the increasing identification of knowledge with the results of research within the bounds of academic disciplines. These had long since been defined in a way that excluded God. But as recently as a century ago, university faculties and the wider public generally agreed that in addition to this form of research there were other types of topics, such as the relation of facts and values, which were also important. The assimilation of evolutionary theory had given rise to speculations about how life, and specifically human life, can come into being that were distinct from the results of research in biology. Whereas the academic discipline of history provided detailed information, it seemed important to locate ourselves in the vast sweep of that history to discern the direction in which humanity was moving. 
By no means were all who concerned themselves with inclusive theories led to affirm a role for God. But many were. Theists like William James $^{1}$, Henri Bergson ${ }^{2}$, and Alfred North Whitehead ${ }^{3}$ were taken seriously by university professors as well as thinkers elsewhere.

This is to say that for a long time the climate of universities allowed for serious discussion of larger questions and for serious efforts to achieve inclusive visions even when these efforts included talk of God. Indeed, many supposed that discussions of these sorts played a major role in departments of philosophy. Accordingly, we must look further to understand their radical exclusion today. I believe the final step in this process centres around the theory of evolution.

As recently as a hundred and fifty years ago, almost everyone in the West, in universities as well as elsewhere affirmed God. Despite the exclusion of God from an explanatory role in science, the study of the physical world confirmed its wonderful complexity and richness. That this world could not have come into being on its own seemed self-evident. Accordingly, the idea that God created the world and the laws on which it operates was the default position of university culture.

Among those who affirmed a creator of the world, there was a marked difference between two groups. There were those who thought that once the creative act was completed, God played no further role. Others thought that God continued to act in the world, and the Christians among them pointed especially to Jesus' resurrection as an act of God. The two groups are sometimes distinguished as 'deists' and 'theists'. Many scientists preferred deism, since it keeps God out of the world they studied, but theistic views were tolerated as long as God's actions were limited to historical events.

Evolutionary theory struck a deep blow at this idea of a divine Creator. Darwin himself remained a deist, believing that the occurrence of evolution required a certain kind of order that it could not itself explain. However, the

${ }^{1} \mathrm{Cf}$. http://www.hup.harvard.edu/collection.php?cpk=1162.

${ }^{2} \mathrm{Cf}$. https://www.questia.com/library/philosophy/20th-and-21st-centuryphilosophy/henri-bergson; and Khandker (2015), http://www.oxfordbiblio graphies.com/view/document/obo-9780195396577/obo-97801953965770259.xml.

${ }^{3}$ https://www.questia.com/library/philosophy/branches-of-philosophy/philo sophy-of-science/alfred-north-whitehead. 
theory took on a life of its own. It gained great power by incorporating Mendelian genetic theory. Its great successes in explaining the coming into being of complex forms of life from simple ones, led to confidence that all the wonders that had been attributed to a Creator could be explained as the working of random mutation of genes and natural selection. The Creator was superfluous, and the insistence of some on pointing to phenomena they thought could be explained only by appeal to God served only as a stimulus to further research. The fact that some believers in God resorted to political opposition to evolutionary theory turned them into enemies, and in the minds of many in university circles, science and religious belief became opponents. Clearly this hardened the exclusion of God.

Since discussion of God was part of a nondisciplinary speculative discourse, the latter also fell into disrepute in universities. There was increasing conviction that efforts should be concentrated on manageable topics. Theories should be floated, only when there were ways of testing them in laboratories or by statistical studies. Classical forms of philosophy seeking comprehensive visions fell into disrepute.

Since reliable knowledge was now understood to be limited to the achievements of the disciplines, and since asking questions about reality in general was disapproved, there was an increasing sense that there is no reality beyond what the academic disciplines study. Of course, new disciplines could be added, but these dealt with limited bodies of data that were recognized as worthy of the same sort of attention as the older disciplines.

All along there were efforts, mostly outside the university to show that one need not choose between God and evolution. These proposals were developed by those believers in God who agreed that the world we know came into being through evolution.

Some accepted the exclusion of God from the world of science, affirming God only in the world of value. Others discerned the hand of God in directing evolutionary developments toward increasing complexity. Some pointed to the more basic laws of the universe as favouring the emergence of life.

These writers were read widely by the general public and provided a basis of continued theistic belief in progressive Protestant circles. The criticisms of the growing university culture were not refuted. Indeed, they were rarely discussed in the university, since the issues were already settled. There was no need for God, and introducing God into the equation was unacceptable. 
Whatever the critics noted as limitations of present scientific theory would be overcome by further research.

\section{III}

In my view the tide that narrowed and rigidified the climate of universities is now beginning to turn. It is true that the dominant university culture is still publicly advancing. The remnants of faculties that had broader concerns are being replaced by disciplinary scholars. But I think that inwardly confidence in the university ideology is eroding. I believe its difficulty in enforcing its orthodoxy is increasing and that it cannot much longer silence the questions of which it has been so contemptuous. This erosion of conviction has many facets, but I select just two.

The orthodoxy I am criticizing excludes a role not only for God but also for any kind of purpose in the explanation of events. There is an inherent absurdity in this exclusion, because it is quite evident that the exclusion of purpose was, and is, a quite purposeful act with widespread ramifications. But I will not dwell on this inherent contradiction.

The exclusion of purpose or 'final cause' from nature at the outset of modern science made a lot of sense. The great weakness of the Aristotelian science of the medieval world was that investigators were too quickly satisfied when they could see 'why' something happened or existed. The heart is 'explained' by the need of an organ to pump blood through the body. In one sense this is, indeed, a valid explanation, but its result was to block inquiry into how this happened. Science could advance significantly only by turning attention to efficient causes. The results of this shift were vast and overwhelming.

However, the fact that much more and much better research could be done by seeking efficient rather than final causes does not necessarily mean that there are no final causes or purposes in the natural world. Denying their existence in sand and gases is one thing. Denying their existence in living things, including human beings is quite another. Indeed, neglecting them in the study of animals on the basis of a priori denial of their existence is a very different matter. Yet this step has followed.

I will illustrate what I take to be the fragility of the now dominant position from my own experience with evolutionary biologists. The standard theory of evolution is carefully formulated to eliminate purpose. There is random mutation of genes that leads to diverse phenotypes. There is natural 
selection of phenotypes. The mutation and the selection are wholly nonpurposive.

However, in fact, it is quite clear that the behaviour of living things also affects evolution. This is true of unicellular organisms as well as monkeys and humans. Lynn Margulis (Sagan 1967; Margulis 1998) demonstrated that the emergence of the nucleated cell, perhaps the single most important step in evolution, took place by symbiosis. In this case, mutations follow on evolutionnary change caused by the behaviour of organisms. Also, it is clear that learning new ways of procuring food, and copying others who procure it in this way, can affect evolutionary development. Again, gene change follows from evolutionary development. What is astonishing is that most evolutionary biologists continue to state, at least for the general public, that random mutation of genes is the engine of evolution. Animal activity is systematically omitted from the theory. This omission continues even though some of these biologists are engaged in purposefully changing the course of evolution by manipulating genes.

Clearly, science has adopted a metaphysics that controls what evidence it will attend to and what theories it will advocate. The denial that scientists have a metaphysics simply serves to avoid thinking about it. The uncritical acceptance of an extremely dubious metaphysics plays a major role in the contemporary climate of universities.

The second illustration I have chosen is parapsychology. According to the metaphysics that is part of the culture of the university, there cannot be any parapsychological phenomena. And, to hold as true, or believe in any of such potential, or related data, does not fit the university system. On the other hand, given the intensity of public interest, for a while, a number of universities in the United States, had separate institutes for research in this broad field. These institutes collected a vast amount of evidence. But now, I understand, all but one have been closed.

Even when research was tolerated and evidence was collected, there was no openness to allowing parapsychology to play any explanatory role in other disciplines. There the standard metaphysics ruled intact. But as time passed, the existence of scientific research in parapsychology became an embarrassment. It was ended. It had always been ignored, but ignoring a field of study is easier when it does not exist on the campus. Today, admitting to belief that there are parapsychological phenomena, or that belief in such, endangers one's status on a university campus.

Modern scientists love to ridicule the Aristotelian scientists at the 
Papal court because they refused to look through the telescope. Galileo knew that what they would see, if they looked, would contradict their metaphysics. They refused to examine evidence that their metaphysics was wrong. I have no desire to defend these scientists. However, contemporary scientists are at least equally guilty of refusing to take into account the vast amount of evidence that their metaphysics is wrong in many ways. This has been going on for a long time.

\section{IV}

There is another price that has been paid in exchange for the great achievements in gaining new knowledge. This is the price of relevance to the major issues facing human kind. There is a disconnect between the organization of inquiry around such issues and organizing it around particular bodies of data. Humanly important problems rarely lie within the province of individual disciplines.

The standard university response is to propose interdisciplinary work. This is certainly needed, and I would not want to discourage it in its still marginal role in universities. But it is far from a panacea. Each discipline can provide interesting information that should be taken account of, in dealing with the problem. But some of the information that is typically needed will not fall in the domain of any of the disciplines.

Perhaps more important, none of them are geared to guiding the transition from being well informed to solving real-world problems. In so far as this transition is taught in universities, this occurs in professional schools. But many of the problems of the world do not fall in the province of a profession.

To test these generalizations we could identify a list of important human problems. Today, one such problem is the growth of poverty around the world. Suppose we approach a modern value-free research university and ask for guidance in reducing poverty. There would be many obstacles. First, we cannot appeal to the idea that helping to reduce poverty is a proper goal of the university. That expresses a particular set of values, and the university is not committed to any such values. The university will commit to such a project only if it is well-funded by an outside source. Since more money is in fact available to fund projects that benefit the wealthy, major research that might lead to support of redistribution is rare. 
Second, if one did have the money to pay for research, one would probably be directed to the department of economics. There one would be told that the goal of the economy is to increase market activity. The distribution of wealth is not a concern. However, economists do have statistics on these matters and some are willing to discuss the effects of various policies on distribution. This would certainly be relevant. But if the inquirer had had experience in the real world, she or he would know that there are cultural, psychological, and sociological dimensions of poverty that are not captured in statistics about distribution.

I will not pursue this example except to say that although students of culture, psychology, and sociology would also provide interesting statistics, the totality of these statistics would be only marginally helpful in the development of programs to reduce poverty. Putting the producers of these statistics into the same room so as to have an interdisciplinary discussion would do little to improve the situation.

Fortunately, there are individuals in all these fields who are themselves genuinely concerned to reduce poverty and who, because of this, have transgressed the boundaries of their disciplines in order to develop genuinely useful ideas and proposals. But this occurs despite the culture of the university, not because of it. If one doubts this, one should read the book by a leading educator, Stanley Fish, addressed to university faculty, entitled Save the World on Your Own Time (2008). 'Saving the world' is not what the university pays them to do.

\begin{abstract}
V
In Section III, I gave reasons for regarding the contemporary university climate as intellectually irresponsible. Scientists often like to point out the intellectual irresponsibility of religious people who, they think, simply take doctrines 'on faith'. But they take at least equally on faith the basic metaphysics associated with modern science. Their methods of enforcing orthodoxy are similar to those of some religious groups, but today they are practiced more by the disciplinary guilds than by religious organizations. Heretics are denied jobs and, if already employed, fired or harried out of the guilds and thereby out of the university. They cannot publish in guild-controlled organs. They are either ignored or pilloried. However, it is my impression that this tight enforcement of orthodoxy is weakening. The story of two heretics gives me hope.
\end{abstract}


The one I know best is Herman Daly. While teaching in economics at Louisiana State University he began to publish critiques of the goal of economic growth adopted by almost all economists ${ }^{4}$. His alternative proposals caught the attention of some readers, and he attracted graduate students. Since he had tenure he could not be fired, but his colleagues began systematically failing students who came to study with him.

As is typical in dealing with heretics, there was little effort to show weaknesses in his arguments or to defend the orthodox view. The true believers closed ranks and closed their ears. He had no choice but to resign. Of course, no other department of economics would hire him. Indeed within academia he was subject to erasure. Occasionally, other economists referred to his ideas (negatively, of course), but they avoided mentioning his name or providing a footnote.

Nevertheless, I am presenting the experience of Daly as the beginning of a move toward an improved situation. From the beginning, he had support from the emerging environmental community. This led to a position at the World Bank. His writings were ignored by economists but read widely by environmentalists and to some extent in the wider community. He was honored with the Right Livelihood Award and other international recognitions.

More relevant to the issue of the climate of the university is that economic orthodoxy has loosened. Economists have to some extent recognized limitations in their orthodoxy. Some have joined in efforts to work with environmentalists. The heir apparent to Daly's leadership role in ecological economics teaches in a department of economics and has not suffered a comparable ostracism from the community. Economic orthodoxy still reigns, but somewhat less confidently or rigidly.

My second example, Rupert Sheldrake, is more dramatic. He was a well-known biologist in England. While living in South Asia, he broke from the dominant mentality of Western universities and began to see that the causation of events, especially those involving life, is much more complex than scientists had allowed. In 1981 he published A New Science of Life: The

${ }^{4}$ Cf. amongst others, his Steady-State Economics ([1977] 1991); with John B. Cobb Jnr, For the Common Good: Redirecting the Economy toward Community, the Environment, and a Sustainable Future ([1989] 1994); Beyond Growth: The Economics of Sustainable Development (1996); and, with Prugh and Costanza, The Local Politics of Global Sustainability (2000). 
John B. Cobb, Jr.

Hypothesis of Formative Causation. This book shocked orthodox biologists. Nature editorialized that it was a candidate for burning. Few tested his theories, but many rejected them out of hand. He became persona non grata in university circles.

However, he was well received in other segments of society, and he pursued the rich field of study opened up by his inclusion of forms of causation rejected by mainstream biologists. He even extended his research into physics. He now offers a comprehensive new science ${ }^{5}$.

Recently he stirred up a widely reported controversy. He presented a harsh critique of the dominant form of science in a TED talk ${ }^{6}$, which was subsequently posted. Representatives of academic orthodoxy were appalled and demanded that it be removed. TED did so ${ }^{7}$.

The good news, from my point of view, is that the story does not end there. If it did, it would be just one more indication of the growing power of scientific orthodoxy. But this time other scientists came to the support of posting Sheldrake's paper. They were opposed to the kind of orthodox censorship that has become commonplace. This new openness of scientists to the publication and discussion of heretical ideas is gaining ground. More scientists are protesting the doctrines and the methods by which they are circumscribed.

\section{VI}

Can we imagine a deep change in the university climate taking place in the relatively near future? I dare to say we can. I believe that there are a very large number of scientists and scholars in other disciplines who really believe that their task is to gain knowledge rather than to defend an outdated orthodoxy. If it becomes widely recognized that universities and their academic disciplines have put orthodoxy above evidence, there could be a scramble to get on the other side. I also believe that many people in academia like to think that what

\footnotetext{
${ }^{5}$ Amongst others, cf. his The Rebirth of Nature: The Greening of Science and God (1992).

${ }^{6} \mathrm{https} / / / \mathrm{www} \cdot$ google.co.za/search?q=What+is+a+TED+talk\%3F\&oq=What + is + a + TED+talk\%3F\&aqs=chrome..69i57j015.4143j0j8\&sourceid=chrome \& ie $=$ UTF- 8 .

${ }^{7}$ Cf. https://www.youtube.com/watch?v=1TerTgDEgUE.
} 
they do, benefits humankind and have not fully appreciated the fact that, because universities and academic disciplines are free of other values, money reigns. Their work is for sale to the highest bidder.

I think that these facts about the present role of universities are becoming more and more evident to persons within universities as well as to external observers. It is not impossible that faculties will engage in study of their own institutions, a topic largely absent from university curricula. And it is not impossible that they will insist on changes.

A first step might be to examine the ideas of heretics on their merits rather than reject them simply because they are not orthodox. For example, scientists might take up proposals of Rupert Sheldrake that they perform certain experiments. If the result is that they show Sheldrake to be mistaken, they can continue to reject his ideas. But if Sheldrake's predictions are supported by the outcome, surely some scientists would accept the need for rethinking long-held doctrines. That would change the climate of the university.

A second step might be for universities to agree that the healthy survival of the human species is a value so widely held that its adoption should be permissible. Many climate scientists have rejected the objective value-free stance and are campaigning for policy changes. I believe that, as more and more professors in various fields recognize the profound threat to humanity of the course of events to which universities now contribute so generously, some will be sufficiently distressed to call for changes. They might suggest that a few students be helped by the faculty to shape their curricula with the goal of contributing positively to the human future.

A third step might be to build on the first two and reconstruct the university quite fundamentally.

\section{VII}

But what about God? God's place in the university is my topic. The changes I have mentioned do not directly affect the exclusion of God.

My argument thus far has been that what has excluded God from the university is its dominant climate shaped by limiting knowledge to value-free disciplines controlled by an unexamined metaphysics. I have suggested that the power of the dominant climate to restrict thought in these ways is weakening. I even claim that change is beginning to happen and that its pace may 
accelerate. Would this end the exclusion of God? My answer is that it would, but that this change would probably come only later.

If the university acknowledges the existence and efficacy of purposes, this would involve the reality and importance of subjects. We could affirm that we live in a community of subjects rather than in the congeries of objects now assumed. The analysis of subjects would lead to recognition of profound interrelatedness. Would this open the door to a role for God?

It is obviously possible to affirm the subjectivity of living things, and even of quanta without introducing God. But it is noteworthy that one of the reasons for going to great lengths to exclude purpose altogether at the outset of the modern period was to deny a foothold to God. Since purpose is not characteristic of machines, the mechanical model will play a more limited role. That means that the existence of purposes opens the door to questions about what else besides the material forces from the past participates in bringing entities with purposes into existence. If the existence of purpose cannot be explained by the preexisting physical world, how is it possible?

The affirmation of purpose need not lead to such questioning. One may simply stop with the fact. Or, one may answer that it is an emergent phenomenon, and stop with that. But the door is opened, and if one does ask, one theory may be that the aim to realize value that seems characteristic of all living things, or the emergence of purpose in the ongoing process of evolution, derives from a cosmic aim to realize value. If there were no prejudice against affirming subjectivity in the universe as a whole, this would be a very natural theory.

However, since the prejudice against God is much stronger than the prejudice against animal and human purposes, any talk of God will remain marginal. Indeed we can expect that those who seek to open the university climate toward the acknowledgment of subjectivity and purpose will strongly emphasize that this does not lead to belief in God. This denial may be an essential part of their strategy.

What would happen if the vast evidence for paranormal phenomena were taken seriously? This would not only reemphasize the importance of subjects but also make clear that their relations do not depend on contiguity. We would learn that our experience is not shaped simply by the physically contiguous events in the brain but also by the more remote past. The universe is as much mental or spiritual as physical. The bias in favour of the data of sense experience would end. 
Clearly, such an understanding of the world is very different from the one that dominates the university. It encompasses all the evidence rather than a selection. And, it provides a context in which the reality of cosmic mind or spirit fits rather comfortably. Nevertheless, because of the prejudice against God, I would not expect God to be an accepted part of the enlarged worldview.

My sense is that for several generations atheists felt secure in their views and believers in God found themselves on the defensive. This climate has certainly weakened the liberal churches. But I am suggesting that pride may come before a fall. The atheists have been so confident that they have felt secure in supporting insupportable policies of refusing to look at evidence and of affirming an incredible world view. For the most part the university culture allows them simply to ignore their failures. But the tide on some topics is turning. We are asking whether that turn will eventually allow the return of God.

I believe that to some extent atheists are already on the defensive on this topic as well. We noted that Darwin thought God was responsible for establishing the basic nature and structure of things in such a way that evolution could work. In his case, this was rather vague. However, science has come a long way, and the result does not show that the world we have is readily understandable or is what could be expected without any controlling purpose at work. On the contrary, the fact that the world supports life at all is truly remarkable, depending on an almost unbelievable set of improbabilities.

No one has attempted any causal explanation of the constants in a scientific sense. That each is what-it-is is seen as a matter of pure chance. Yet if any one of them had been even a little different, life would not have been possible. The probability of any one of them being what-it-is is very small. That all are just what they are is almost infinitely improbable.

Darwin would not have been surprised. This is just what he expected of God. So it would seem easy for scientists to say, the most likely explanation is that this expresses the divine purpose that there be life. However, the university culture is not open to that hypothesis. The only allowable explanation is that this truly remarkable circumstance is a matter of pure chance. One can hardly imagine any other topic on which such an explanation would even be considered.

Some scientists do try to reduce the incredulity that this explanation is likely to arouse outside the university culture by another kind of speculation. 
If there have been an infinite number of universes, then the fact that one of them has these almost infinitely improbable features is no longer improbable. And of course since that is the only universe on which there is life, it is the only one on which questions of this kind can arise.

This speculation is possible, but in my judgment, highly improbable. We have come to accept very improbable theories from scientists, and the idea that there have been multiple universes is now widely agreed upon. The one theory of multiple universes that is sufficiently plausible for us to pay serious attention to, is an argument that derives from Big Bang cosmology. Although the Big Bang theory is itself not fully established, I will formulate the argument for infinite universes in its terms.

In these terms it is reasonable to suppose that the Big Bang that initiated this universe with its particular constants was preceded by the Big Crunch of a preceding universe. Hence we have at least two successive universes. Does this justify extrapolating to an infinite number?

To do this we must assume that every previous universe arose in a Big Bang and ended in a Big Crunch. This is, of course, possible. However, we should recall that cosmologists are not sure that our universe will end its expansion and turn toward the Big Crunch. For this to occur there are certain requisites that may or may not characterize our universe. Yet the theory of infinite universes requires that in every case in the past those requisites were met. That is, of course, possible.

This would mean that all the trillions of past universes were very similar in crucial ways. That, too, is possible. The laws that govern this universe may govern all universes, and they may all have the character that leads to a Big Crunch followed by another Big Bang. I am prepared to grant the plausibility of an infinite succession.

The basis on which this theory gains plausibility is that the universes are quite similar. If they varied much, one of them along the way would have just kept expanding forever and brought an end to the series. On the other hand, the reason for bringing this theory up was to show that if there have been an infinite number of universes each of which has a chance set of constants, the one highly improbable set that makes life possible would eventually occur. We have, then, the supposition that the most fundamental laws of the universe would be profoundly different in successive universes, but that the conditions that produce the Big Crunch has been present in all. The improbability of such a combination is overwhelming. 
My point is not that this theory is impossible. Much happens by chance. But I doubt that such an extreme improbability would be put forward with a straight face for any other purpose than to exclude God. I regard it as a defensive act. It is a sign that if one is open to the possibility of a spiritual being operative in the universe as a whole, then one will find that the extreme improbability of alternative explanations justifies the belief that this spirit has purposefully established the fundamental laws of the universe so as to make life possible. One may also view this spirit as explanatory of the purpose that pervades living things.

I personally judge that the Cosmic Spirit, God, aims at the increase of value, and that every entity derives from God the aim to achieve what value is possible for it. I find this understanding existentially meaningful and even empowering. I would like to see universities also dedicate themselves to the increase of value (1) in the lives of their students; (2) by orienting thought and research to the common good; and (3) by seeking wisdom rather than supporting outdated metaphysics. I believe that such universities would serve God whether they acknowledged this or not. And, in the long run I believe that acknowledging and even celebrating this fact would strengthen them in this service.

\section{References}

Bergson, H. n.d. Henri Bergson. Questia. Available at:

https://www.questia.com/library/philosophy/20th-and-21st-centuryphilosophy/henri-bergson

Fish, S. 2008. Save the World on Your Own Time. Oxford: Oxford University Press.

Daly, H.E. [1977] 1991. Steady-State Economics. ${ }^{\text {nd }}$ Edition. Washington, DC: Island Press.

Daly, H.E. \& J.B. Jr. Cobb [1989] 1994. For the Common Good: Redirecting the Economy toward Community, the Environment, and a Sustainable Future. $2^{\text {nd }}$ Updated and Expanded Edition. Boston: Beacon Press.

Daly, H.E. 1996. Beyond Growth: The Economics of Sustainable Development. Boston: Beacon Press.

James, W. n.d. The Works of William James. Harvard University Press.

Available at: http://www.hup.harvard.edu/collection.php?cpk=1162

Khandker, W. 2015. Henri Bergson. Oxford Bibliographies. Available at: 
John B. Cobb, Jr.

http://www.oxfordbibliographies.com/view/document/obo-

9780195396577/obo-9780195396577-0259.xml

Margulis, Lynn 1998. Symbiotic Planet. New York, NY: Basic Books.

Prozesky, M. 1992. A New Guide to the Debate about God. London \& Pietermaritzburg: SCM \& University of Natal Press.

Prugh, T.R. Constanza \& H.E. Daly 2000. The Local Politics of Global Sustainability. Washington, DC: Island Press.

Sagan, L. 1967. On the Origin of Mitosing Cells. Journal of Theoretical Biology 14,3: 225-274. doi:10.1016/0022-5193(67)90079-3.

PMID 11541392.

Sheldrake, R. 1981. A New Science of Life: The Hypothesis of Formative Causation. Michigan: F.P. Tarcher Incorporated.

Sheldrake, 1992. The Rebirth of Nature: The Greening of Science and God. Rochester: Park Street Press.

Whitehead, A.N. n.d. Alfred North Whitehead. Questia. Available at: https://www.questia.com/library/philosophy/branches-ofphilosophy/philoso-phy-of-science/alfred-north-whitehead

John B. Cobb Jr. Former Ingraham Professor of Theology Claremont School of Theology, and Avery Professor of Religion at Claremont Graduate University Claremont cobbj@cgu.edu 